University of Nebraska - Lincoln

DigitalCommons@University of Nebraska - Lincoln

April 1989

\title{
Agribusiness Skills Required by Agriculture Students as Perceived by Nebraska Vocational Agriculture Instructors and Agribusiness Managers
}

\author{
David R. Spotanski \\ lowa State University \\ Richard M. Foster \\ University of Nebraska - Lincoln
}

Follow this and additional works at: https://digitalcommons.unl.edu/aglecfacpub

Part of the Other Public Affairs, Public Policy and Public Administration Commons

\begin{abstract}
Spotanski, David R. and Foster, Richard M., "Agribusiness Skills Required by Agriculture Students as Perceived by Nebraska Vocational Agriculture Instructors and Agribusiness Managers" (1989). Faculty Publications: Agricultural Leadership, Education \& Communication Department. 17. https://digitalcommons.unl.edu/aglecfacpub/17
\end{abstract}

This Article is brought to you for free and open access by the Agricultural Leadership, Education \& Communication Department at DigitalCommons@University of Nebraska - Lincoln. It has been accepted for inclusion in Faculty Publications: Agricultural Leadership, Education \& Communication Department by an authorized administrator of DigitalCommons@University of Nebraska - Lincoln. 


\title{
Agribusiness Skills Required by Agriculture \\ Students as Perceived by Nebraska Vocational Agriculture Instructors and Agribusiness Managers
}

\author{
David R. Spotanski, Graduate Student \\ Iowa State University \\ Richard M. Foster, Professor \\ University of Nebraska
}

Agribusiness instruction in vocational agriculture programs can help prepare employees for service related job opportunities in agriculture. Many employment opportunities can be found in occupations related to food and fiber production, transportation, processing, packaging, storing, advertising, and distributing. These jobs are numerous and diverse, strengthening the link between farm products and the consumer (Steward, 1987) .

The need for trained employees in non-farm agricultural occupations has been well documented in the decade of the 1960's (Williams, 1971). Cooper (1985), reported there is a need for continuous expansion and revision of competencies for employment in agriculture/agribusiness occupations. Birkenholz and Stewart (1986), found that local programs were less than adequate in preparing students for careers in agribusiness. Priebe (1986) surveyed 1,312 business firms and reported that entry level agribusiness opportunities were good because they required little work experience and low levels of education. To advance professionally, the student must seek higher levels of education; often a baccalaureate degree.

Litzenberg (1987) remarked, that any effective agribusiness education program in the future will require a commitment of time and money from public and private agricultural interests. Future agribusiness programs will depend heavily on the educator's ability to develop curriculum and to provide relevant course materials to current instructors of agribusiness education.

It has become the responsibility of agricultural educators to determine present and future agribusiness needs and to revitalize agricultural education. The development of curriculum which prepares students to enter the occupations of their choices is the major reason for the existence of vocational educators at all levels (Matteson, 1974). Secondary and postsecondary vocational educators are ultimately responsible for the development of appropriate vocational education curriculum.

\section{Purpose and Objectives}

The purpose was to identify agribusiness skills required by a student for entry level employment in Nebraska agribusinesses. The specific objectives were:

1. To determine agribusiness skills perceived to be required for employment, by Nebraska agribusiness managers and vocational agriculture instructors.

2. To determine differences between the perceived importance of selected skills required for employment in an agribusiness, by Nebraska vocational agriculture instructors and agribusiness managers. 


\section{Procedures}

The population was secondary vocational agriculture instructors in Nebraska and the managers of businesses serving agriculture in the communities offering vocational agriculture programs. Three instructors were randomly selected from each of 12 NVAA districts in Nebraska. Instructors were asked to identify names and addresses of managers of seven different types of agribusiness in their community based on the following criteria:

(a) the business should employ at least 10 people;

(b) the business should be agriculturally related;

(c) the business should provide employment opportunities for secondary and postsecondary agricultural graduates;

(d) the business should represent one of each of the following agribusiness areas; production agriculture, agricultural supplies, agricultural sales and service, agricultural finance, agricultural mechanics, manufacturing, and horticulture. The final respondent sample consisted of 36 Nebraska vocational agriculture instructors and 180 agribusiness managers.

Sixteen instructional units identified in the Mid America Vocational Curriculum Consortium (MAVCC) guide for teaching Employment in Agriculture (1986) served as the source for selecting 66 specific agribusiness skills for a pilot study. Fifty agribusiness managers and vocational agriculture instructors from across the state were selected to pilot test the instrument. Forty-one survey items were then identified for inclusion in the final study. The 41 items were divided into agribusiness skill areas: (a) skills to obtain employment in an agribusiness; (b) general business skills; (c) sales skills; (d) office equipment skills; (e) communication skills; and, (f) customer relation skills. A rating scale of 1 to 9 was used to determine the perceived importance of each skill as an employment requirement in an agribusiness $(1=$ a skill was not required for employment in an agribusiness; 3 = seldom required; 5 = sometimes required: 7 = required; and, 9 = essential for employment).

Data were collected by using a mailed survey. Nonrespondents were personally contacted and encouraged to participate after two follow-up mailings. Thirty 'vocational agriculture instructors returned completed surveys for a return rate of 83\%; 140 agribusiness persons returned completed surveys for a $78 \%$ return rate.

\section{Analysis of Data}

When evaluating the rated skills, the following guidelines were established by the investigators: a score of $1-3.99$ identified skills that were seldom to never required; a score of 4 to 6.99 identified skills that were sometimes required; and, a score of 7 or above identified skills that were required.

Descriptive statistics, and t-test procedures were used to analyze survey items which were considered important for employment in an agribusiness, A Cronbach Alpha Reliability Coefficient was calculated on the instrument yielding a value of $\underline{r}=.94$. An independent $\underline{\mathbf{t}}$-test was used to determine differences between sample means of primary respondent groups and late respondents. No differences were found. 
Mean scores of the 41 agribusiness skills as perceived by agriculture instructors and agribusiness managers are reported in Table 1 . The agribusiness respondent group identified seven skills as required for employment in their agribusiness. These skills included: (a) the ability to get along with people; (b) obtain a social security card; (c) use the telephone; (d) use the adding machine: (e) talk to customers; (f) utilize product knowledge for customer relations; and, (g) recognize/help customers.

Table 1

Means, t-values for Skills Required to Gain Employment in an Agribusiness

Employment Skills Instr $(\underline{\mathbf{N}}=30) \quad \operatorname{AgBus}(\underline{\mathbf{N}}=140) \quad \underline{\mathbf{t}}$-vehe

1. Skills Required to Obtain Employment Social security

Employment application

7.63

8.57

8.33

Resume

7.93

7.90

Letter of application

6.27

Calculate take home pay

7.70

7.83

Count change

Prepare sales ticket

Accept credit cards/checks

7.47

Calculate percentages

6.97

Figure sales tax

Calculate discounts

7.47

7.07

Order/receive merchandise

6.53

Complete purchase order

6.63

Balance cash register

7.23

Check cash balances

6.80

Calculate interest

6.37

Computer/word processing

5.80

Calculate profit/loss

5.90

Program a computer

3.63

7.98

6.98

5.93

5.24

5.02

4.86

$-0.78$

$3.85 * *$

$5.83 * *$

$6.21 * *$

$6.96 * *$

$2.85 * *$

3. Sales Skills

Possess product knowledge

7.70

6.10

$2.74 * *$

Close a sale

7.23

6.04

$3.17 * \star$

Maintain inventory

Plan/create a display

Prepare a newspaper ad

Select advertising media

Plan a floor layout

Determine stock turnover

6.57

6.07

5.81

$2.58 * *$

$2.96 * *$

$3.40 * *$

5.50

3.21 **

$2.46 * \star$

5.42

$3.17 * *$

$4.11^{* *}$

3. 91 **

$3.29 * *$

$4.19 * *$

$4.20 * *$

$2.79 * *$

\subsection{0}

5.97

4.89

4.64

4.57

3.86

3.82

2.56

$2.00 * *$

5.17

6.72

$2.83^{* *}$

5.74

$2.85^{* *}$

5.22

3.52 *

4.82 *

3.28

$6.02 * *$

5.63

3.45

3.84 *

4. Office Equipment Skills

Use telephone

8.37

$5.03 * *$

Use adding machine

Use cash register

7.67

7.69

1.75

7.63

7.54

0.34

Use micro fiche

5.80

5.29

$3.74 * \star$

Operate computer

6.57

4.45

$2.25 * *$

$4.45 * *$

5. Communication Skills

Get along with people

8.71

8.24

1.96

(table continues) 
Talk to customers

Introduce yourself and others Organize/present a demo Speak to large groups

6. Customer Relation Skills Possess product knowledge Recognize/help customers Handle complaints
8. 50

7. 70

6. 63

6. 47

8. 30

7.97

7. 60
1. 41

6. 50

4. 74

4. 62

7. 38

7. 11

6. 87
2. $78^{* *}$

3. $06^{* *}$

4. $44 * *$

4. $62^{* * *}$

Note. $\star(\mathbf{D}<.05), * \star(\mathbf{p}<.01)$.

The instructors identified 22 skills as required for employment in an agribusiness. Instructors and agribusiness managers agreed on seven skills. These skills included: (a) obtaining a social security card; (b) using the telephone; using the adding machine; (c) the ability to get along with people; (d) the ability to talk to customers; (e) the ability to introduce yourself and others; (f) product knowledge to improve customer relations; and, (g) the ability to recognize and help customers.

Thirty-six skills were observed to be significantly different at the .05 level when comparing perceptions of importance of skills required for employment between instructors and managers. Further testing indicated that 30 skills produced significant differences at the .01 level.

Agribusiness respondents identified seven skills as seldom or never required for employment in an agribusiness. These skills included: (a) the ability to use computer word processing skills; (b) calculate profit/loss: (c) program a computer; (d) prepare a newspaper advertisement; (e) select advertising media; (f) plan a floor layout: and, (g) determine stock turnover. Agribusiness respondents identified the customer relation skill group (Table 2) as the most required skill group for employment in an agribusiness. Communication skills ranked second in importance followed by skills to obtain employment, All composite mean scores for the six agribusiness skill groups were significantly different at the .01 level. Vocational agriculture instructors rated all skill groups higher than the agribusiness managers.

Table 2

Means, and $t$-values of Composite Scores for Six Skills Areas Required for Employment in an Agribusiness

$\begin{array}{llll}\text { Customer Relation Skills } & 7.96 & 6.96 & \mathbf{2 . 4 6 *} \\ \text { Communication Skills } & \mathbf{7 . 6 1} & \mathbf{6 . 2 4} & \mathbf{4 . 4 5 ^ { * * }} \\ \text { Employment Skills } & \mathbf{7 . 7 7} & 5.93 & \mathbf{7 . 0 9 ^ { * * }} \\ \text { Office Equipment Skills } & 7.21 & 5.71 & \mathbf{4 . 2 2 * *} \\ \text { Business Skills } & \mathbf{6 . 6 7} & \mathbf{4 . 8 8} & \mathbf{4 . 9 1 * *} \\ \text { Sales Skills } & \mathbf{6 . 2 4} & \mathbf{4 . 4 0} & \mathbf{5 . 0 0 ^ { * * }}\end{array}$

Nate. * $(\mathbf{p}<.05), * \star(\mathbf{p}<.01)$. 
The majority of employment skills and competencies currently provided in instructional materials used in Nebraska vocational agriculture programs were rated as only sometimes required or not required by agribusiness managers. Agribusiness managers rated skills consistently lower and did not require as many skills to gain employment as perceived by vocational

agriculture instructors. Customer relation skills and communication skills were the most required skill categories identified by Nebraska agribusiness managers. Curriculum materials used to provide agribusiness instruction in Nebraska should be reviewed and updated to enhance appropriate materials. Required employment skills should be identified and instructional materials developed to meet the needs of the agribusiness employer. Agribusiness persons and vocational agriculture instructors should work cooperatively on this task. Instructors should discuss and identify appropriate agribusiness skills required for employment with agribusiness managers in the area. Vocational agriculture instructors and local agribusiness persons should promote opportunities for students to improve the communication skills needed to gain employment. Customer relation skills and communication skills should be taught in all vocational agriculture programs with agribusiness in the curriculum.

Additional research should be conducted to determine what actual skills and competencies are currently required for employment in an agribusiness. The last national competency study was completed during the years of 19751978.

References

Birkenholz, R.J. \& Stewart, B.R. (1986, December). Factors Associated with Adjusting Vocational Agriculture Programs a.s Perceived by Teachers. Reported at the Thirteenth Annual National Agricultural Research Meeting.

Cooper, E.L. \& Hilton, H.L. (1985, May). Vocational Agricutlure/Agribusiness Bmployment Needs Assessment in st. Marys', Charles, Calvert, and Anne Arundel Counties, Maryland. Proceeding's of the Eastern Region Annual Research Conference in Agricultural Education. Easton, Maryland. 144 p. (ERIC Document Reproduction Service No. ED 255 677)

Hilgenberg, G. \& Huston, J. (1984). Employment in Agribusiness. (1st edition). Mid-America Curriculum Consortium Inc. Stillwater, Oklahoma, (ERIC Document Reproduction Service No. ED 271 559)

Litzenberg, K.K. \& Schneider, V.E. (1987). Agribusiness Manaaement Aptitude and Skills Survey. Washington, D.C., Texas A\&M University. Agribusiness Education Project.

Matteson, H.R. (1974). Function-Task Competencv Approach to Curriculum Development in Agriculture. Madison, Wisconsin. College of Agriculture and Life Sciences, University of Wisconsin.

Priebe, D. (1986). Emplovment Opportunities and Training Needs of Eight Selected North Dakota Industries. Fargo, North Dakota. North Dakota University. Division of Agricultural Education.

(References continued on page 13) 